Pino Saavedra

\title{
Palabras desoladas
}

I

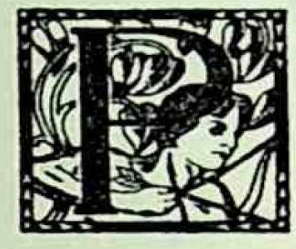

ORQUE mi corazón está indeciso...

De mis sueños de amor quiebro los últimos, y renace otro sueño, enardecido.

Bandadas de besos en los bosques tuyos... Saldrá a cazar mi corazón altivo, -flechas innúmeras hacia el luturo.-

Gimen mis voces, las goteantes voces de mi desolación, por tu llegada, para que los recuerdos no se asomen.

Llegas a mi heredad esperanzada. Rompo mis jarras porque se desborden de placer las locuras de mi alma.

Llegas a mi heredad, la misma y otra... En tu frente está azul el horizonte, y una palabra atroz quema tu boca.

Pájaros ebrios de mi agria tristeza, batid las alas con rumor de bronce, porque el prodigio no esperado sea.

Un viejo afán se me desata, y vibro; pero la voz se anuda a mi tristeza, porque mi corazón está indeciso. 
Huyo de ti, y la voz se me desata a gritos; te encuentro en todas partes, de todas partes huyo, y estoy con este amor fatal y agradecido de no haber alcanzado nada que fuera tuyo.

Ahl mujer, aunque ajena, yo te llevo por mía en la tristeza gris, en la voz y en el verso. Ah! mujer, los poetas, como los niños, hilan con un vellón de ensueño un enorme universo.

Tú serás de otro. Tú derrocharás tu orgullo sobre la desventura de mi pasión en ruinas, haz de recuerdos tristes por haber sido tuyo y la desolación de que no eres mía.

Llamamiento de todas las palabras orantes y una hoguera de súplicas que incendia mi tristeza, por este grande y viejo amor que tú no sabes que por sobre la vida el corazón te besa.

Y es inútil la huída. Por donde voy te llevo: cauce loco, extraviado, que arrastra un mismo río, ebrias alas que vuelan bajo unos mismos cielos, corazón que se arranca de sus propios latidos.

\section{III}

Porque no habrás de hallarlo, mi corazón te espera... Mi juventud se cimbra, invisible y serena, en un vaivén terrible de amor y de tristeza.

Porque no habrá de hallarte, mi corazón te busca... Como al partir de un puerto para no volver nunca, mis pupilas se llenan de lágrimas obscuras. 


\section{Palabras desoladas}

En la paz de mi alma tu amor se desvanece.

El sueño de mi vida se hace más persistente, $\mathrm{y}$ en los brazos del mundo mi tristeza se duerme.

¡Canción de advenimiento! ¡Canción de despedida! ¡Doloroso recuerdo cuando tu vida, un día, no halle la senda por donde mi amor se iba!

Fatalidad de todo lo vivido y perdido... Tal como un astro muerto abrumado de siglos, estará en lo Infinito mi corazón dormido. 